\title{
Characterizing Contaminant Concentrations with Depth by Using the USGS Well Profiler in Oklahoma, 2003-9
}

\section{By S. Jerrod Smith and Carol J. Becker}

\section{Introduction}

Since 2003, the U.S. Geological Survey (USGS) Oklahoma Water Science Center has been using the USGS well profiler to characterize changes in water contribution and contaminant concentrations with depth in pumping public-supply wells in selected aquifers (fig. 1). The tools and methods associated with the well profiler, which were first developed by the USGS California Water Science Center (Izbicki and others, 1999), have been used to investigate common problems such as saline water intrusion in high-yield irrigation wells (Izbicki and others, 2005) and metals contamination in highyield public-supply wells (Ball and Izbicki, 2004).

The USGS well profiler (fig. 2) is a slim (less than 1 inch in diameter), high-pressure hose that can be raised and lowered between the production pipe and casing (or borehole) of a well by using a motorized hose reel. Use of this tool is considerably less expensive than use of standard methods of depth-dependent sampling, and the USGS well profiler generally requires less downtime of the well. In terms of data quality, the greatest advantage of the USGS well profiler is that all data collection is performed under production pumping rates.

In Oklahoma, the USGS well profiler has been modified and adapted for use in low-yield (150-350 gallons per minute) wells of various construction types common in Oklahoma. This tool has been used in selected public-supply wells in Hinton, Moore, and Norman to identify which producing zones are contaminated by naturally occurring arsenic (fig. 1). The tool and method also can be used to investigate other nonvolatile contaminants of interest, including uranium, radium, barium, boron, lead, selenium, sulfate, chloride, fluoride, nitrate, and chromium.

In 2007, the USGS well profiler was used to investigate saline water intrusion in a deep public-supply well completed in the Ozark (Roubidoux) aquifer (Pope and others, 2009; fig. 1). In northeast Oklahoma, where the Ozark aquifer is known to be susceptible to contamination from mining activities (Christenson, 1995), the well profiler also could be used to investigate sources (depths) of metals contamination and to identify routes of entry of metals to production wells.

Water suppliers can consider well rehabilitation as a potential remediation strategy because of the ability to identify changes in contaminant concentrations with depth in individual wells with the USGS well profiler. Well rehabilitation methods, which are relatively inexpensive compared to drilling and completing new wells, involve modifying the construction or operation of a well to enhance the production of water from zones with lesser concentrations of a contaminant or to limit the production of water from zones with greater concentrations of a contaminant. One of the most effective well rehabilitation methods is zonal isolation, in which water from contaminated zones is excluded from production through installation of cement plugs or packers. By using relatively simple and inexpensive well rehabilitation methods, water suppliers may be able to decrease exposure of customers to contaminants and avoid costly installation of additional wells, conveyance infrastructure, and treatment technologies.

\section{Prescreening and Selection of Wells for Investigation}

The following criteria can be used to identify production wells that are appropriate candidates for investigation with the USGS well profiler:

1. The community can manage water-supply needs without the use of the well during the testing period (usually 2-3 days).

2. The well has a minimum 10-inch-diameter casing or open borehole with greater than 2 inches of clearance between the production pipe and casing or borehole wall.

3. The well has a minimum 1.5-inch-diameter access port at the wellhead that allows vertical access inside the casing.

4. The well has a sampling port (spigot, fig. 2) in the production line (preferably at the wellhead) that allows collection of representative samples of produced water.

5. The well has a bypass (fig. 2) that allows produced water to be discharged to the surface without entering the distribution system. 
Some additional criteria, though not required, can also be considered because they increase the likelihood of sampling success with the USGS well profiler:

6 . The well has a 1.25-inch-diameter slotted polyvinyl chloride (PVC) access tube attached to the pump column.

7. The well has a pump set high in the well rather than near the bottom of the well to facilitate tool access.

8. The production well is able to pump continuously for 10 hours per day for up to 5 consecutive days (the maximum duration of sampling activities; Smith and others, 2009).

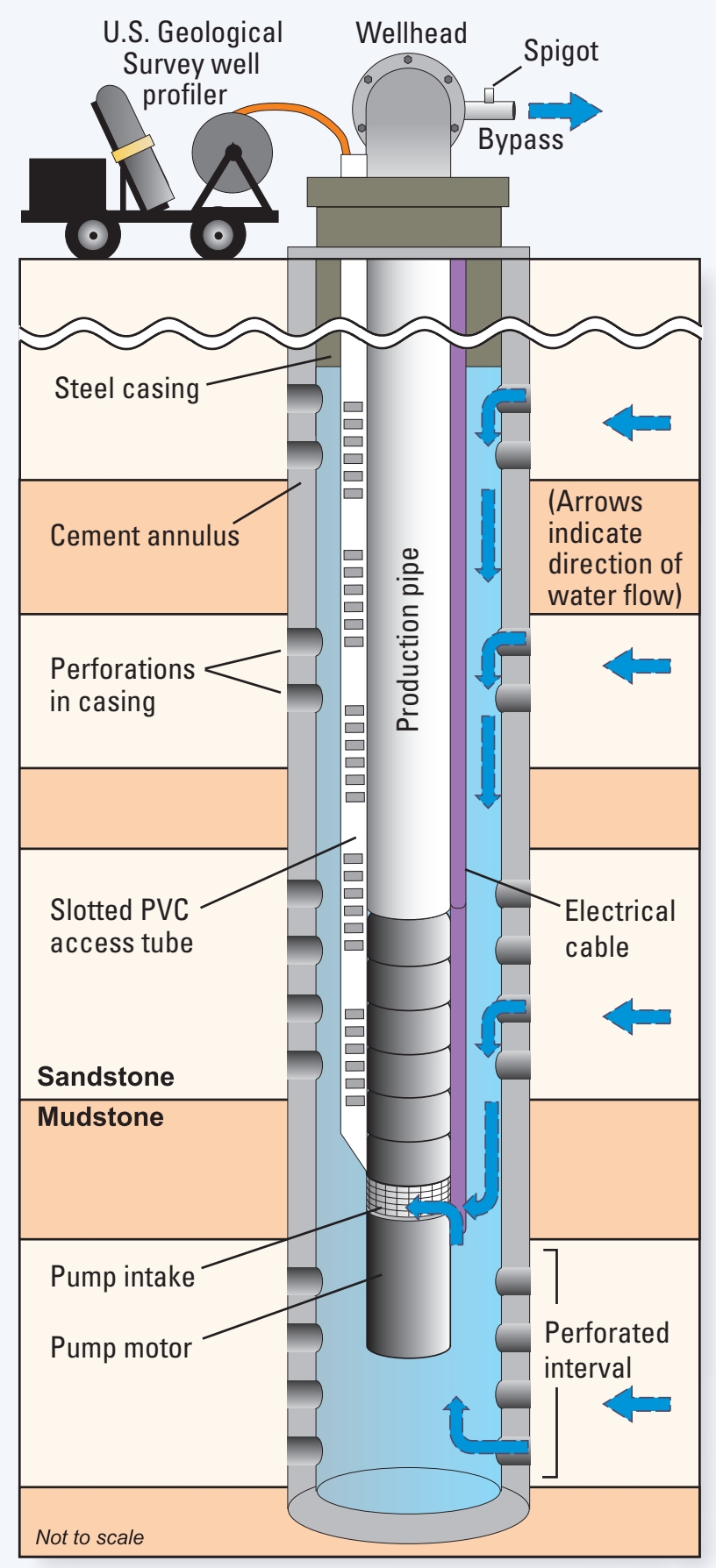

Figure 2. Gun-perforated well and deployment of the U.S. Geological Survey well profiler (modified from Smith and others, 2009).
Many municipal public-supply wells completed in the Garber-Wellington aquifer (GWA), Rush Springs aquifer (RSA), Ozark aquifer, and possibly other Oklahoma aquifers (fig. 1) satisfy these construction criteria. Most domestic, stock, and irrigation wells, however, cannot be investigated by using the USGS well profiler because the well diameters are too small.

Historical wellhead contaminant analyses, if available, also can be useful for identifying wells that might have differences in water quality with depth. Arsenic concentration can be used as an example: some wells (for example, well 05, fig. 3) have large variations in wellhead arsenic concentrations over time. Though wellhead samples represent unknown mixtures of water coming into the well at different depths, variation in reported arsenic concentrations over time indicates that a well has differences in water quality with depth (Smith and others, 2009). If data were accurately reported and water chemistry of contributing zones has remained relatively constant over the life of the well, then there must be at least one zone in the well that produces water with arsenic concentrations equal to or greater than the maximum measured concentration (for example, 150 micrograms per liter $[\mu \mathrm{g} / \mathrm{L}]$ for well 05 , fig. 3 ). Likewise, there must be at least one zone that produces water with arsenic concentrations equal to or less than the minimum measured concentration (for example, $2 \mu \mathrm{g} / \mathrm{L}$ for well 05 , fig. 3 ). The difference between the maximum and minimum detected concentrations, therefore, gives some indication of the range in water quality to expect if depth-dependent samples were collected. If all wellhead samples are nearly equal in arsenic concentration over time, then there may be little variation in water quality with depth and little potential for successful remediation by well modification.

\section{Case Study: Arsenic}

In 2001, the U.S. Environmental Protection Agency (USEPA) reduced the maximum contaminant level (MCL) for arsenic in public drinking water from $50 \mu \mathrm{g} / \mathrm{L}$ to $10 \mu \mathrm{g} / \mathrm{L}$ (U.S. Environmental Protection Agency, 2001a). As a result of the new standard, the USEPA estimated that about 3,000 public water providers across the United States must take action to meet the new standard, which became effective on January 23, 2006 (U.S. Environmental Protection Agency, 2001b).

In Oklahoma, at least 23 public water-supply systems have been affected by the reduced arsenic MCL (J. Craig, Director, Water Quality Division, Oklahoma Department of Environmental Quality, written commun., 2005). These public water-supply systems range in size from about one hundred customers to tens of thousands of customers. Larger municipal water suppliers often are financially able to address noncompliant concentrations of arsenic in drinking water, but affordable options are limited for small communities and rural water districts, which operate on limited resources, maintain minimal conveyance infrastructure, and have no secondary source of water. Well modification to exclude arsenic-bearing water from existing wells is a more cost-effective solution than chemical treatment and infrastructure-based methods, but well modification requires knowledge about local aquifer properties and individual well dynamics to determine which wells are good candidates for modification. In a series of projects from 2003 through 2009 , the USGS well profiler was used to investigate with-depth changes in arsenic concentrations in the GWA and the RSA. 


\section{Arsenic Concentrations in the Garber-Wellington Aquifer}

Norman, Moore, and many other municipalities in the Oklahoma City metropolitan area draw water from the GWA. The GWA underlies about 3,000 square miles in central Oklahoma (Parkhurst and others, 1996; fig. 1). The processes and conditions that lead to elevated arsenic in the GWA are fairly well understood; a USGS National Water-Quality Assessment (NAWQA) study, beginning in the late 1980s and concluding in the mid 1990 s, determined the rock composition, water chemistry, and groundwater movement in the aquifer (Parkhurst and others, 1996; Schlottmann and others, 1998). These NAWQA findings were integrated into a comprehensive conceptual model that is useful for explaining phenomena and patterns of arsenic concentrations observed spatially across the aquifer.

In some parts of the GWA, arsenic concentrations in water are small, but concentrations as great as 232 $\mu \mathrm{g} / \mathrm{L}$ have been measured in Norman (Schlottmann and others, 1998; Smith and others, 2009). Generally, concentrations of arsenic in water of the GWA tend to increase with depth. Municipal wells in the western portion of the GWA, which are typically 600-900 feet deep, are more likely to exceed the arsenic MCL than are deep wells completed in the eastern portion (Schlottmann and others, 1998). Arsenic concentrations in water are commonly elevated in only one or two zones, however, usually near the bottom of the well (fig. 4). If these zones can be identified and sealed off (isolated) from production, a well may produce water with lesser concentrations of arsenic, but any decrease in arsenic concentration at the wellhead likely would be paired with a decrease in well yield when using this type of remediation method.

\section{Arsenic Concentrations in the Rush Springs Aquifer}

The RSA underlies about 2,300 square miles in western Oklahoma (fig. 1). In contrast to the GWA, very little is known of the extent, degree, and cause of arsenic contamination in the RSA. To date, no comprehensive water-quality studies have been performed with appropriate method-reporting levels and spatial distribution of samples to characterize the arsenic contamination problem. Public-supply wells in the RSA are usually open-hole completions, with depths of about 300 feet. Most wellhead arsenic concentrations measured in regulatory compliance samples range from less than 1 to $40 \mu \mathrm{g} / \mathrm{L}$ (J. Craig, Director, Water Quality Division, Oklahoma Department of Environmental Quality, written commun., 2005). Very few data, however, have been collected regarding arsenic concentrations with depth in the RSA, and the mechanism of arsenic release to water has not been determined.

Nearly all of the public water suppliers that produce water from the RSA are smaller systems which have limited resources to support remediation activities. In addition, these systems usually rely on the RSA to supply 100 percent of their water needs.

\section{Arsenic Concentrations in Other Aquifers}

Arsenic also has been identified as a contaminant of concern in other Oklahoma aquifers that serve as minor sources of

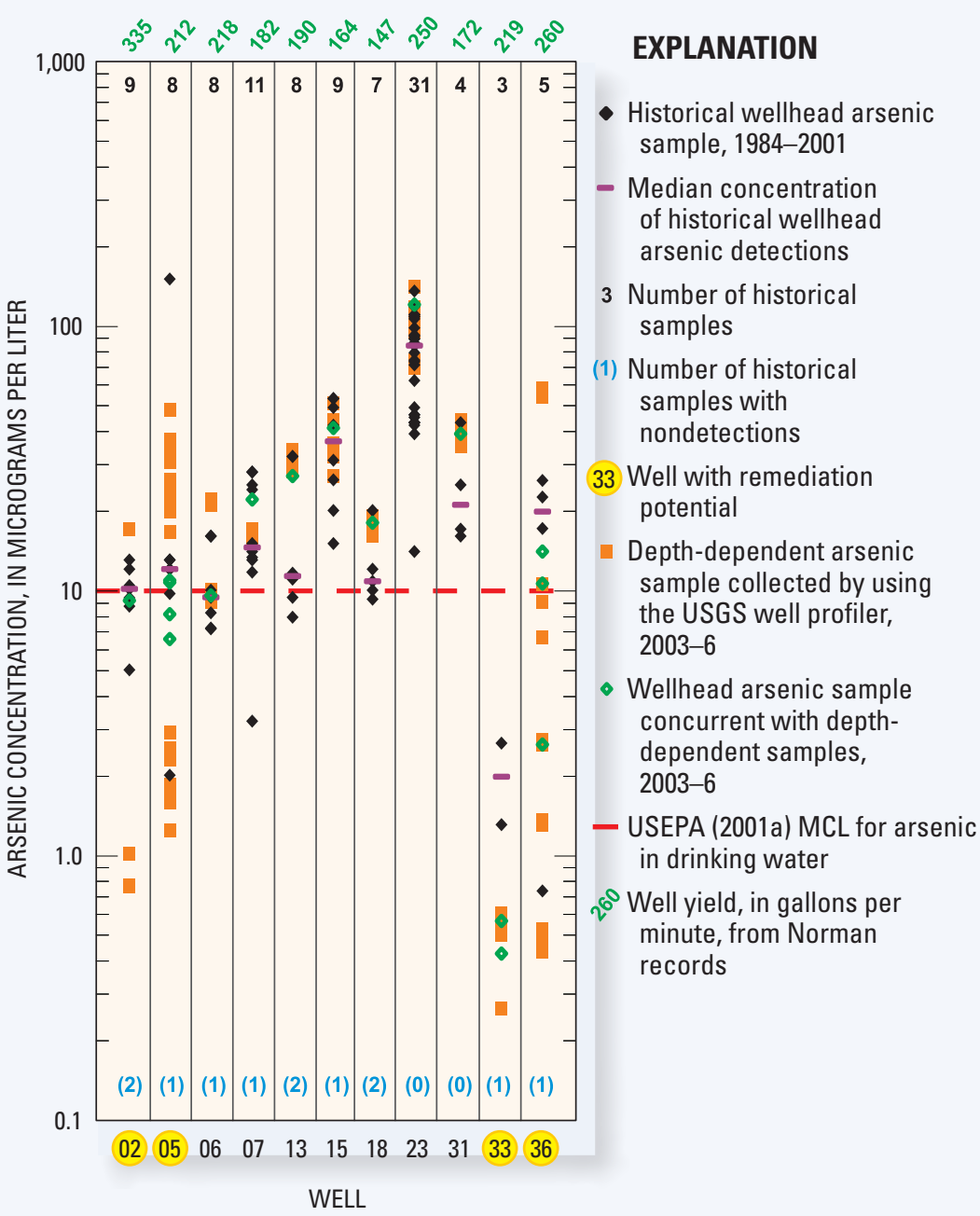

Figure 3. Wellhead arsenic concentrations for 1984-2001 and median values for arsenic in the Norman, Oklahoma, well field, with depth-dependent and wellhead arsenic concentrations from 11 selected wells, 2003-6 (modified from Smith and others, 2009).

water. For example, the Arbuckle-Timbered Hills Aquifer in southwestern Oklahoma (fig. 1) is known to produce water with arsenic concentrations exceeding $10 \mu \mathrm{g} / \mathrm{L}$ (Becker and others, 2010). Public-supply wells in the Arbuckle-Timbered Hills aquifer also commonly exceed the MCL for fluoride (Becker and others, 2010). The occurrence and extent of arsenic and fluoride contamination could be investigated simultaneously by using the USGS well profiler.

\section{Adapting Technology}

As of 2010, the USGS well profiler has been used to investigate water-quality concerns in 12 public-supply wells completed in the GWA (Smith and others, 2009; Becker and others, 2010), 1 public-supply well completed in the RSA (Becker and others, 2010), and 1 public-supply well completed in the Ozark aquifer (Pope and others, 2009). For each deployment, the tool can be adapted to access each well. The versatility of the tool makes it very useful for collecting water-quality data because of the variety of wellhead, well-completion, well-house, and landscape configurations in Oklahoma. Thus, the USGS well profiler could be applied to water-quality investigations in largediameter wells completed in a variety of aquifers in Oklahoma and surrounding regions. 


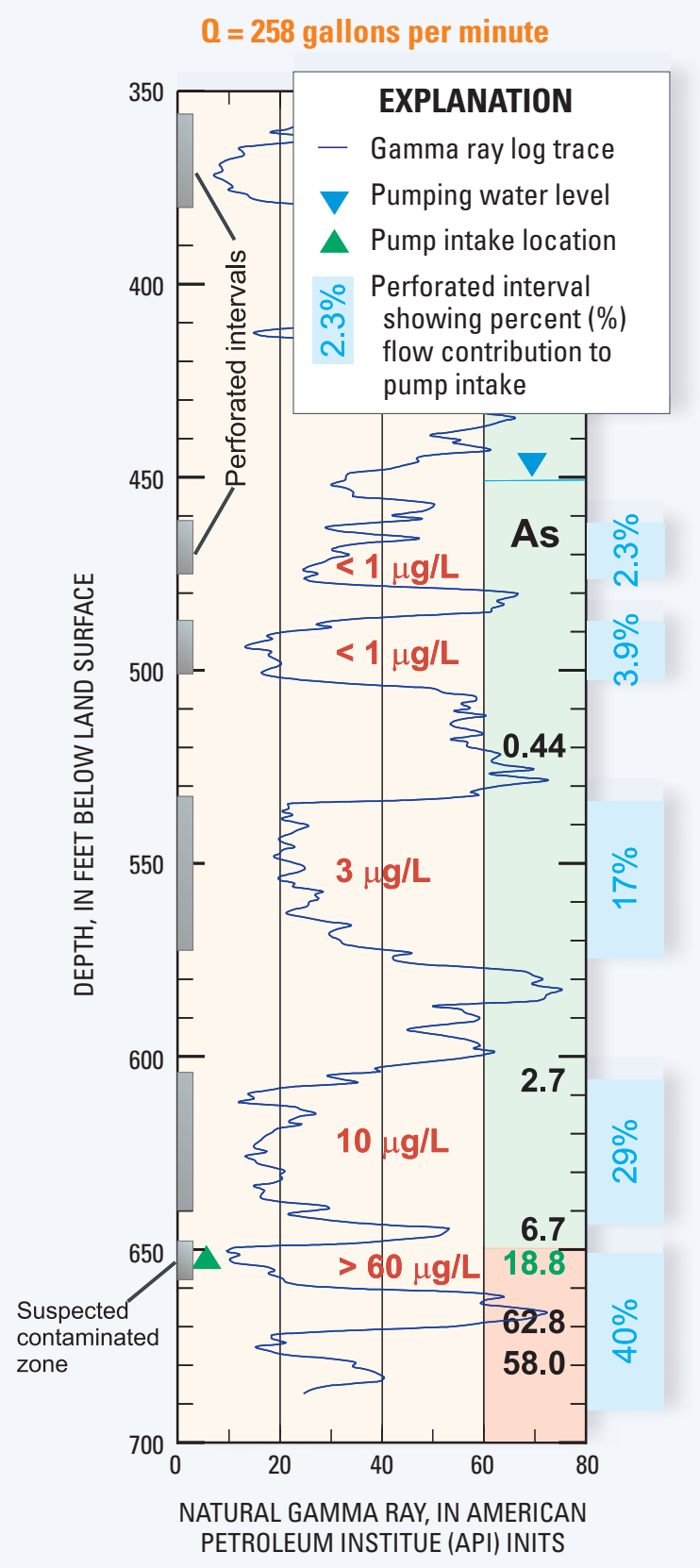

Figure 4. Results of well profiling in a Norman, Oklahoma, public-supply well completed in the Garber-Wellington aquifer. Concentration data in green type are from wellhead samples; those in black type are from depth-dependent samples at the indicated depth. Concentrations in red type are estimated arsenic concentrations in produced water from perforated intervals (modified from Smith and others, 2009) [0, production rate; As, dissolved arsenic in micrograms per liter $(\mu \mathrm{g} / \mathrm{L})]$.

\section{Selected References}

Ball, J.W., and Izbicki, J.A., 2004, Occurrence of hexavalent chromium in ground water in the western Mojave Desert, California: Applied Geochemistry, v. 19, no. 7, p. 1123-1135.

Becker, C.J., Smith, S.J., Greer, J.R., and Smith, K.A., 2010, Arsenic-related water quality with depth and water quality of well-head samples from production wells, Oklahoma, 2008: U.S. Geological Scientific Investigations Report 2010-5047, 38 p. (Also available online at http://pubs.usgs. gov/sir/2010/5047/)
Christenson, S.C., 1995, Contamination of wells completed in the Roubidoux aquifer by abandoned zinc and lead mines, Ottawa County, Oklahoma: U.S. Geological Survey WaterResources Investigations Report 95-4150, 114 p.

Izbicki, J.A., Christensen, A.H., and Hanson, R.T., 1999, U.S. Geological Survey combined well-bore flow and depthdependent water sampler: U.S. Geological Survey Fact Sheet 196-99. (Also available online at http://pubs.usgs.gov/ $\left.f_{S} / 1999 / f_{S} 19699 /\right)$

Izbicki, J.A., Christensen, A.H., Newhouse, M.W., Smith, G.A., and Hanson, R.T., 2005, Temporal changes in the vertical distribution of flow and chloride in deep wells: Ground Water, v. 43 no. 4, p. 531-544.

Parkhurst, D.L., Christenson, S.C., and Breit, G.N., 1996, Ground-water-quality assessment of the Central Oklahoma aquifer, Oklahoma-Geochemical and geohydrologic investigations: U.S. Geological Survey Water-Supply Paper 2357-C, $101 \mathrm{p}$.

Pope, L.M., Mehl, H.E., and Coiner, R.L., 2009, Quality characteristics of ground water in the Ozark aquifer of northwestern Arkansas, southeastern Kansas, southwestern Missouri, and northeastern Oklahoma, 2006-07: U.S. Geological Survey Scientific Investigations Report 2009-5093, 61 p. (Also available online at http://pubs.usgs.gov/sir/2009/5093/)

Schlottmann, J.L., Mosier, E.L., and Breit, G.N., 1998, Arsenic, chromium, selenium, and uranium in the Central Oklahoma aquifer, in Christenson, S.C., and Havens, J.S., eds., Groundwater-quality assessment of the Central Oklahoma aquifer, Oklahoma-Results of investigations: U.S. Geological Survey Water-Supply Paper 2357-A, p. 119-179.

Smith, S.J., Paxton, S.T., Christenson, S., Puls, R.W., and Greer, J.R., 2009, Flow contribution and water quality with depth in a test hole and public-supply wells - Implications for arsenic remediation through well modification, Norman, Oklahoma, 2003-2006: U.S. Environmental Protection Agency Report 600/R-09/036, 147 p., accessed March 31, 2011, at http:// www.epa.gov/ada/gw/arsenic.html.

U.S. Environmental Protection Agency, 2001a, National primary drinking water regulations; arsenic and clarifications to compliance and new source contaminants monitoring-Final rule: Federal Register 66, no. 14, p. 6976-7066.

U.S. Environmental Protection Agency, 2001b, Technical fact sheet-Final rule for arsenic in drinking water. (Also available online at http://water.epa.gov/lawsregs/rulesregs/sdwa/ arsenic/regulations_techfactsheet.cfm.)

For more information contact:

S. Jerrod Smith U.S. Geological Survey 202 NW 66th Street Oklahoma City, OK 73116 sjsmith@usgs.gov

Publishing support provided by Lafayette and Rolla Publishing Service Centers. 